\title{
Ecosystem response to changes in water level of Lake Ontario marshes: lessons from the restoration of Cootes Paradise Marsh
}

\author{
Patricia Chow-Fraser \\ Department of Biology, McMaster University, Hamilton, ON, Canada L8S 4K1 \\ E-mail: chowfras@mcmaster.ca
}

Key words: restoration, water level, Great Lake, Lake Ontario, emergent vegetation, submersed aquatic vegetation, coastal wetland

\begin{abstract}
A general understanding of how aquatic vegetation responds to water-level fluctuations is needed to guide restoration of Great Lakes coastal wetlands because inter-annual and seasonal variations often confound effects of costly remedial actions. In 1997, common carp (Cyprinus carpio) was removed from Cootes Paradise Marsh (L. Ontario) to reduce sediment resuspension and bioturbation, and thus regenerate marsh plants that had declined dramatically since the 1930s. Data from 1934 to 1993 were re-assembled from the literature to relate percentage cover of emergent vegetation to mean summer water level. A non-linear regression equation explained close to $90 \%$ of the variation compared with $80 \%$ for a non-linear equation, and this trend was confirmed for the dominant species, Typha latifolia. A modest recovery of emergent vegetation in 1999 following carp exclusion could have been predicted from declining water level alone, without invoking any effects of the biomanipulation. An unusually cool spring in 1997 delayed the migration of spawning planktivores into the marsh. This resulted in a grazer-mediated clear-water phase that coincided with a resurgence of the submersed aquatic vegetation (SAV) community in 1997, which declined again in 1999 when low water levels occurred. Even though decrease in water level was significantly related to increased suspended solids and greater light attenuation, light conditions appeared to have been adequate in marsh embayments to support SAV growth, according to a published relationship between maximum depth of SAV colonization and light extinction coefficient. I suggest that wave disturbance and propagule burial associated with shallow water depths may have been the main reasons for the decline of the SAV in 1999 and 2000.
\end{abstract}

\section{Introduction}

The Laurentian Great Lakes, along with their connecting channels, are an imposing physical feature of North America. They span more than $1200 \mathrm{~km}$ from west to east, contain about $23000 \mathrm{~km}^{3}$ of water, and cover a total area of $244000 \mathrm{~km}^{2}$ (Environment Canada \& U.S. Environmental Protection Agency, 1995). As of 1995, these waters provided consumption, transportation, power, and recreation to 33 million people in the Great Lakes watershed. In addition, the approximately $18000 \mathrm{~km}$ of coastline provide critical habitat for many of Great Lakes fish, waterfowl and wildlife communities, especially in coastal marshes that are formed in shallow, protected lake margins, and river-mouths. A very prominent hydrologic feature of these wetlands is the large seasonal and inter-annual water-level fluctuation, that can range by up to several meters from year to year and from $50 \mathrm{~cm}$ to $3 \mathrm{~m}$ episodically (Lenters, 2001). The inter-annual variability is primarily due to long-term changes in precipitation and air temperatures (Quinn, 2002), while the well-defined seasonal cycles are driven primarily by meteorological conditions as well as watershed characteristics (Quinn, 2002; Argyilan \& Forman, 2003). 
Water-level fluctuations are known to contribute to the great diversity of aquatic vegetation in coastal wetlands by keeping them in a perpetual state of disturbance, and preventing them from becoming dry fields (Keddy \& Reznicek, 1986; Herdendorf, 1992; Wetzel, 1992). The timing of seasonal maxima as well as magnitude of flooding in spring can also affect the health of the Great Lake fish community. During years of low waterlevel, fish cannot access the coastal marshes to spawn (Chow-Fraser \& Albert, 1999; Wei et al., 2004), and if drawdown is sustained for several years, the submergent and floating vegetation can be greatly diminished or eliminated, and this can lead to loss of critical nursery habitat for many warm-water fish.

During the 1990s, governments in both Canada and the U.S. began to recognize the great ecological value of coastal wetlands for migratory birds, fish spawning and nursery habitat and initiated large-scale and costly wetland restoration projects. Cootes Paradise Marsh, an urban wetland of Lake Ontario, is one such wetland currently being restored. Because of its size and location, it is an important migratory stop for waterfowl, as well as a major fish nursery for Lake Ontario. At the turn of the century, $90 \%$ of the marsh was covered by a diverse community of emergent and submergent vegetation; however, in the past three decades, the percentage cover of emergent plants has declined to $<15 \%$ and the community is currently dominated by Typha xglauca and Glyceria maxima, both of which are exotic to N. America (Chow-Fraser et al., 1998).

A number of papers have been published that document the pre-manipulation condition of the seed bank (Westcott et al., 1997; Sager et al., 1998) and the quality of the marsh based on waterquality and community structure of the lower food-web (Sager, 1996; Chow-Fraser et al., 1998; Lougheed \& Chow-Fraser, 1998; Lougheed et al., 1998; Chow-Fraser, 1999a). More recently, investigators have documented post-manipulation conditions, focusing on the response of the aquatic vegetation (Lundholm \& Simser, 1999; Smith et al., 2001), water quality and zooplankton community (Lougheed \& Chow-Fraser, 2001, 2002) and the interaction between the lower food web and the planktivore community (Lougheed et al., 2004). However, investigators have not accounted for the direct and indirect effects of water-level fluctuations when assessing the effectiveness of carp exclusion on the emergent and submergent communities.

The goal of this paper is to determine the response of the marsh to carp exclusion by accounting for the confounding effects of interannual variation in water levels. First, I will determine if the percentage emergent cover calculated by Smith et al. (2001) for the 1999 season departs significantly from that predicted by Chow-Fraser et al. (1998) based on water-level alone. Secondly, Lougheed \& Chow-Fraser (1998) predicted that water clarity would improve by $25-30 \%$ after carp exclusion, but since this relationship can be confounded by differences in water depth, I will determine if data obtained after exclusion (1997-2000) depart significantly from predictions based on a relationship between total suspended solids and water level derived during the pre-exclusion period. Thirdly, I will determine the likelihood that light conditions in Cootes Paradise have been limiting the growth of submersed aquatic vegetation (SAV) as suggested by Painter et al. (1989). I will use light-extinction data collected from 1994 to 2001 to calculate $Z_{\max }$, the maximum depth for growth of SAV (e.g. Hudon et al., 2000); a comparison of $Z_{\max }$ with mean water depths in the marsh should reveal if there is a basis for expecting light limitation in the marsh. I hope that results from this study will provide general guidance to others contemplating restoration and offer some insight on how inter-annual changes in water levels can affect the re-establishment of aquatic vegetation in degraded coastal marshes of the Great Lakes.

\section{Description of study site and the Remedial Action Plan}

The marsh is located at the extreme west end of Lake Ontario, and flows into Hamilton Harbour, a busy natural harbour that is connected to Lake Ontario through the Burlington ship canal (Fig. 1 inset). Like other coastal wetlands, Cootes Paradise is relatively shallow, with a calculated mean residence time of $11.63 \mathrm{~d}$ and a maximum depth of $1.7 \mathrm{~m}$ in the open-water sites during high-water years (Chow-Fraser, 1999a). Complete details of its hydrology, characteristics of the watershed and the food-web changes over the past 60 years 


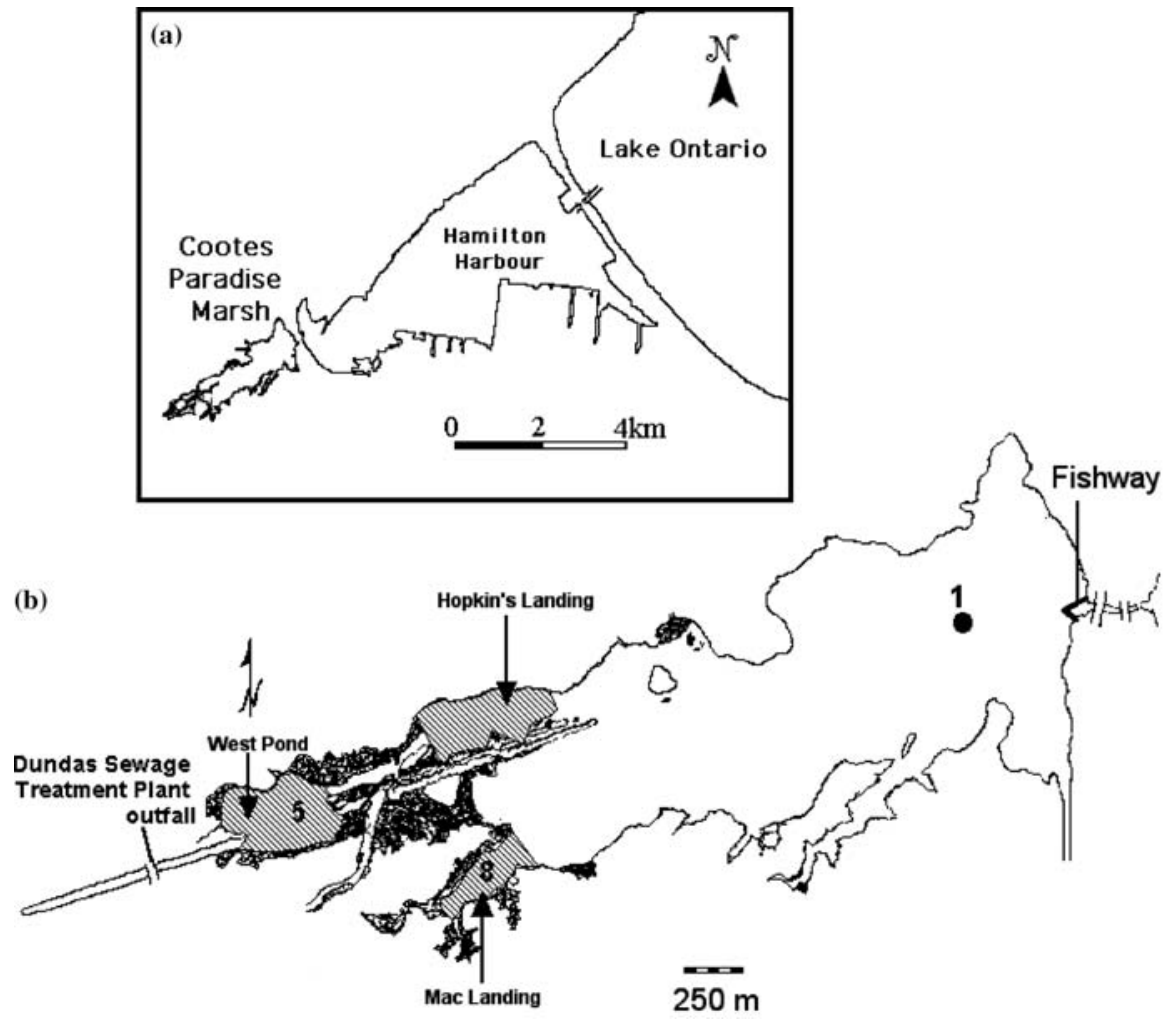

Figure 1. Map of Cootes Paradise Marsh showing location of the Fishway at the outlet to Hamilton Harbour. Station ' 1 ' in Cootes Paradise Marsh is the open-water station. Stipled areas indicate the embayments delineated for this study to examine changes in Typha distribution between 1946 and 1979. The inset map shows the location of Hamilton Habour and the Burlington Ship Canal, which connects the harbour to Lake Ontario, and where water levels of Lake Ontario have been recorded since 1970.

have been documented elsewhere (Chow-Fraser et al., 1998; Lougheed \& Chow-Fraser, 1998, 1999a). The marsh deepens gradually from west to east, with the deepest part near the outflow. During a high-water year in 1993, water depths at the open-water station (Site 1) reached a maximum of $1.65 \mathrm{~m}$ in early May, but dropped throughout the summer to a minimum of $0.75 \mathrm{~m}$ by late August; by contrast, during 1994, a low-water year, water depths reached a maximum of $1.10 \mathrm{~m}$ in May and declined to $0.70 \mathrm{~m}$ by late August (Chow-Fraser, 1999a). Therefore, despite the inter-annual difference of about half a meter at the beginning of the season, water depths by the end of the summer were almost the same. The shallowest depths occurred in protected embayments in the west end of the Marsh (e.g. Mac Landing; Fig. 1), where water depths ranged from $0.80 \mathrm{~m}$ to mudflat by the end of August in 1993 and from $0.60 \mathrm{~m}$ to mudflat in 1994 (Chow-Fraser, 1999a).
Causes for the decline of marsh vegetation in Cootes Paradise is well documented (Painter et al., 1989; Sager et al., 1998; Chow-Fraser et al., 1998; Chow-Fraser, 1998; Lundholm \& Simser, 1999; Chow-Fraser, 1999a; Lougheed \& Chow-Fraser, 2001; Angeler et al., 2003). Loss of emergent vegetation has been attributed to sustained high water levels over the past 30 years, while the disappearance of submergent vegetation is thought to be due to poor light penetration that is assumed to be limiting germination and growth of seedlings and propagules. The fish community in the marsh is currently dominated by common carp (Cyprinus carpio), a benthivorous feeder that grows well in the eutrophic, turbid conditions of the marsh, and whose feeding and spawning behaviour keep the waters turbid (Lougheed \& Chow-Fraser, 1998; Chow-Fraser, 1999a). Besides resuspending sediment and keeping water turbidity high, carp can also uproot submergent plants and exclude 
other wetland species from using the marsh for nursery habitat (Crivelli, 1983).

With funds from the Hamilton Harbour Remedial Action Plan, the Royal Botanical Gardens, owner and manager of the marsh, planned and carried out a carp exclusion program to restore Cootes Paradise Marsh. Since large fish migrate into the marsh to spawn every spring, they usually leave by late summer before water levels drop to low levels. Hence the marsh is essentially devoid of fish in the beginning of each season in January or February. A fishway-barrier complex, called the 'Cootes Paradise Fishway' (see Fig. 1) was built at the mouth of Cootes Paradise to obstruct the passage of migratory fish (including carp) (see Wilcox \& Whillans, 1999; Smith et al., 2001 for details on how the Fishway is operated). In Spring of 1997, the Cootes Paradise Fishway became operational: all fish other than carp were prevented entry into the marsh, and this reduced the contribution of common carp to only $10 \%$ of the total fish community biomass, whereas in the previous 2 years, they accounted for up to $90 \%$ (Lougheed et al., 2004). One of the main goals of carp exclusion is therefore to reduce sediment resuspension and bioturbation associated with spawning and feeding behaviours of carp, in order to provide better light penetration for the growth of submergent vegetation.

\section{Methods}

\section{Water level data}

Continuous water levels have been recorded by the Marine Environmental Data Services Branch of the Department of Fisheries and Oceans since 1970 at station 13150, which is located at the Burlington ship canal. Daily records from January 1970 to December 2000 were obtained from the Tides, Currents and Water Levels at the Canada Centre for Inland Waters, Burlington. I referenced all data to the 1985 International Great Lakes Datum (IGLD), and then converted them to corresponding data for Cootes Paradise using the predictive equation developed in Chow-Fraser et al. (1998). This equation relates water level values measured at a benchmark established in Mac Landing, Cootes Paradise to data from
Station $13150 \quad\left(n=38 ; r^{2}=0.88 ; p<0.0001\right)$. Next, monthly means were calculated for the $31-y$ database, and then a summer mean was calculated for each year, which included the mean values from May to September (inclusive). For years prior to 1970, I used data reported in Lavender (1987; cited in Chow-Fraser et al., 1998), which had been collected by the Department of Fisheries and Oceans at a Toronto, Ontario station.

\section{Percentage emergent cover}

All percentage emergent cover data were obtained from published sources. Data for 1934-1993 were obtained from Chow-Fraser et al. (1998) and from Smith et al. (2001) for 1999. Several methods were used to determine aerial cover and have been fully described in their published sources. Briefly, data for 1934, 1950, 1954, 1959, 1961, 1962, 1969, 1972, 1974,1980 , and 1985 were determined from digitized aerial photographs (1:1400 to 1:50,000 scale). The 1990 value was determined by planimetry of a colour aerial photograph (1:5000). The remaining data were determined from vegetation maps that had been prepared from intensive field surveys (with a standardized transect sampling protocol) conducted by staff of the Royal Botanical Gardens. All of the maps were digitized and imported into ARCINFO for determination of percentage cover. In all cases, the aerial photography and vegetation surveys were carried out in late summer.

I used the GIS database from vegetation maps (based on field surveys) to examine changes in Typha latifolia in three of the embayments from 1946 to 1979 . To facilitate statistical evaluations, I arbitrarily delineated the boundaries of Mac Landing, West Pond and Hopkin's Landing (stipled areas in Fig. 1). I then used Arcview version 3.2 to calculate the percentage area occupied by $T$. latifolia in each embayment during 1946, 1953, 1971, 1974, 1975, 1978 and 1979. Data from subsequent years were unsuitable for analysis of $T$. latifolia because the RBG staff had lumped this species with other emergent taxa.

\section{Water quality data}

All water-quality data in this study were measured with established protocols documented in previous 
studies on Cootes Paradise Marsh (Lougheed \& Chow-Fraser, 1998, Chow-Fraser et al., 1998; Chow-Fraser, 1999a). Data for only three of the 18 long-term sites mentioned in Chow-Fraser (1999a) are reported here: Site 1, an open-water station, Site 5, a lagoon into which effluent from the Dundas Wastewater Treatment Plant empties, and Site 8, Mac Landing, which still contains residual marsh vegetation (Fig. 1).

On a biweekly basis from May to September in 1993-2001, the marsh was sampled at the three long-term sites listed above. Because of low water levels (minimum of $40 \mathrm{~cm}$ ) after August in some years, sampling could only be carried out in the deeper, open-water station after mid-August. Sampling was generally carried out between 10:00 and 15:00, under sunny or overcast conditions (not immediately after or during rain events) to reduce variability in the data. Wind speeds were measured with an anemometer in a canoe and corresponding wind directions were recorded at the same time. Water samples were collected in triplicate from mid-column (maximum depth sampled was $1.7 \mathrm{~m}$ ) and turbidity (TURB) measurements were determined immediately with a Hach 2100 P Turbidimeter. In situ measurements of temperature (TEMP), specific conductance (COND) were also recorded with a Hydrolab ${ }^{\mathrm{TM}}$ H20 sonde equipped with a Scout2 monitor. Secchi depth transparencies were recorded in triplicate with a $20-\mathrm{cm}$ black and white disc. A LiCor photometer equipped with spherical submersible sensor was used to obtain underwater PAR at $10-\mathrm{cm}$ intervals from the surface to within $20-\mathrm{cm}$ of the sediment surface. These were used to calculate light extinction coefficients (EXTINCT), which is the negative slope of the regression of the natural log of light intensity against depth (m).

Water samples were collected with a horizontal 1-L Van Dorn bottle from the middle of the water column for nutrient and suspended solids analyses. Water was placed in acid-washed Nalgene bottles for nutrient analysis and were either frozen or acidified as required, and stored at $5{ }^{\circ} \mathrm{C}$ until analysis. Total phosphorus (TP) was analysed in triplicate according to the molybdenum-blue method of Murphy \& Riley (1962); absorbances were measured with a Spec 301 spectrophotometer and converted to concentrations based on regularly calibrated standard curves (Milton Roy Ltd.,
Hong Kong). Samples for total suspended solids (TSS) were first filtered through pre-weighted GF/ $\mathrm{C}$ filters and then frozen. They were dried at $100{ }^{\circ} \mathrm{C}$ for $1 \mathrm{~h}$, placed in a desiccator for $1 \mathrm{~h}$ and then weighed to the nearest $0.0001 \mathrm{~g}$ using an OHAUS AS 120 balance. Filters were subsequently combusted at $550{ }^{\circ} \mathrm{C}$ for $20 \mathrm{~min}$ and desiccated for $1 \mathrm{~h}$ to determine ash-free weights or total inorganic suspended solids (TISS). Concentration of total organic suspended solids (TOSS) was calculated as the difference between TSS and TISS.

\section{Relationship between percentage cover and water level}

Areal cover of all emergent vegetation from each of the 20 years published in Chow-Fraser et al. (1998) were plotted against the mean summer (May-September, inclusive) water level as described above, and SAS JMP 5.1 (Statistical Analysis Systems, Cary, N.C.) was used to derive both a quadratic equation and a least-squares linear regression equation for the data. The 95\% confidence interval around the best-fit line was also determined for the quadratic equation. Similar analyses were performed for the percentage cover of $T$. latifolia against water level obtained for the three embayments.

\section{Relationship between TSS and water level}

I used data from the long-term monitoring program carried out by Chow-Fraser et al. (1999a) to develop a relationship between seasonal mean TSS and seasonal mean water level for Site 1 in Cootes Paradise Marsh. Only data from Site 1 were included because it is the only station that had been monitored continuously on a biweekly basis between May and September from 1986 to 2000.

\section{Estimation of $\mathrm{Z}_{\max }$}

There was no historic information from Cootes Paradise Marsh to develop the relationship between light and the maximum depth at which SAV can be established, commonly called $Z_{\max }$. I therefore used published studies, primarily based on lake data (Chambers \& Kalff, 1985; Duarte et al., 1986) and river data (Hudon et al., 2000) to 
relate SECCHI and EXTINCTION to $Z_{\max }$ values. EXTINCTION data generally require more effort to collect than SECCHI data, but they can provide more accurate information since SECCHI readings do not accurately reflect water clarity when light penetrates to the bottom in shallow areas. There was only one relationship that related $Z_{\text {max }}$ to EXTINCTION values (Hudon et al., 2000). Although this relationship had not been derived from lacustrine marshes, the data had been collected from open marshes along the St. Lawrence River, which have similar hydrological characteristics to Cootes Paradise Marsh.

\section{Submergent plant survey}

Thirteen permanent transects were laid out across Cootes Paradise Marsh in June of 1996 to obtain a cross section of marsh vegetation (Lundholm \& Simser, 1999). Submerged macrophyte populations in areas of open water along the transect lines were counted in June of each year from 1996 to 2000. All stems of submerged species in a standard width centred along the length of the transect were counted; from 1996 to 1997, the width of the transect was 3-m, but after 1998, the width was reduced to $0.50 \mathrm{~m}$ because of increased plant density. The length of each transect was multiplied by the width to generate the total area sampled. Stem counts were divided by area to generate total stem density per species for each transect. Only plants that reached the top $5 \mathrm{~cm}$ of the water column were counted, to reduce the bias resulting from underestimating stem density when water clarity was poor. In this study, I only report results from transects taken in the embayments located in the western portion of the marsh (i.e. transects 6 a, 6b, 6c, 7 and 8 in Lundholm \& Simser, 1999).

\section{Results}

\section{Emergent Vegetation}

I assembled both pre- and post-exclusion data from published papers to determine the relationship between percentage emergent and water level for Cootes Paradise Marsh (Fig. 2a and b); there were 20 data points for the pre-exclusion period (19341993 from Chow-Fraser et al., 1998), and one for the post-exclusion period (1999; Smith et al., 2001). I performed both a linear and non-linear (quadratic) analysis (Fig. $2 \mathrm{a}$ and b, respectively) to derive a best-fit line through the pre-exclusion data. The polynomial regression equation explained almost $10 \%$ more of the variation in the data than did the linear regression equation $\left(r^{2}=0.89\right.$ vs. 0.80 in Fig. $2 \mathrm{~b}$ and a, respectively). I then used both equations to predict the percentage cover corresponding to the 1999 water level of $74.79 \mathrm{~m}$. The polynomial regression predicted $23.09 \%$ while the linear regressions predicted a higher value of


Figure 2. (a) Linear regression and (b) non-linear regression of percentage area versus water level (m, asl) for Cootes Paradise Marsh. Data from 1934 to 1993 were obtained from ChowFraser et al. (1998), and the 1999 data point was obtained from Smith et al. (2001). Data point for 1999 was not included in the regression analyses. Lines corresponding to the $95 \%$ Confidence Interval of the best-fit line are shown in each panel. Labels above data points correspond to the year. 
$28.36 \%$. The actual amount of emergent cover measured by Smith et al. (2001) was $18.8 \%$, a value that falls well within the $95 \%$ confidence interval corresponding to both the linear and non-linear regressions (Fig. 2).

I wanted to see if this non-linear response to water levels could be ascribed to individual plant taxa. For this analysis, only 8 of the 20 years had detailed distribution data corresponding to Typha latifolia, a dominant species in the marsh during the 1930s and 1940s. The percentage cover of $T$. latifolia in two embayments of Cootes Paradise Marsh (i.e. Hopkins Bay and West Pond; Fig. 3a and b, respectively) declined nonlinearly with increased water level. Although there was a similar relationship for Mac Landing, the relationship was not statistically significant (Fig. 3c). Consistent with the earlier analysis, the linear regression analysis explained less of the residual variation than did the polynomial regression.

\section{Water quality}

Chow-Fraser (1999a) documented significant siteto-site and seasonal variation in water-quality of Cootes Paradise Marsh prior to carp exclusion. Since water-clarity parameters such as EXTINCTION, SECCHI, TURB and TSS tended to vary temporally and spatially, the effect of carp exclusion must be assessed on a site-by-site basis. I have summarized the comparison of physico-chemical variables before and after carp exclusion in Cootes Paradise Marsh to illustrate the differences among sites for these basic limnological variables (Table 1). The most consistent difference between periods for all three sites are significant reductions in TURB and TISS following carp exclusion. As will be discussed later, the improvement in water clarity may have been related to a general trend towards shallower depths following biomanipulation, as well as significantly calmer conditions in Mac Landing. Water conductivity at Site 1 was significantly higher after carp exclusion, but this trend was not repeated at the two other sites. Besides the obvious difference in water transparency, there were no significant changes in water temperature or TP concentrations between periods for any of the sites.
In 1995, Lougheed \& Chow-Fraser (1998) conducted experiments using twelve $50-\mathrm{m}^{2}$ enclosures in which the biomass of carp had been
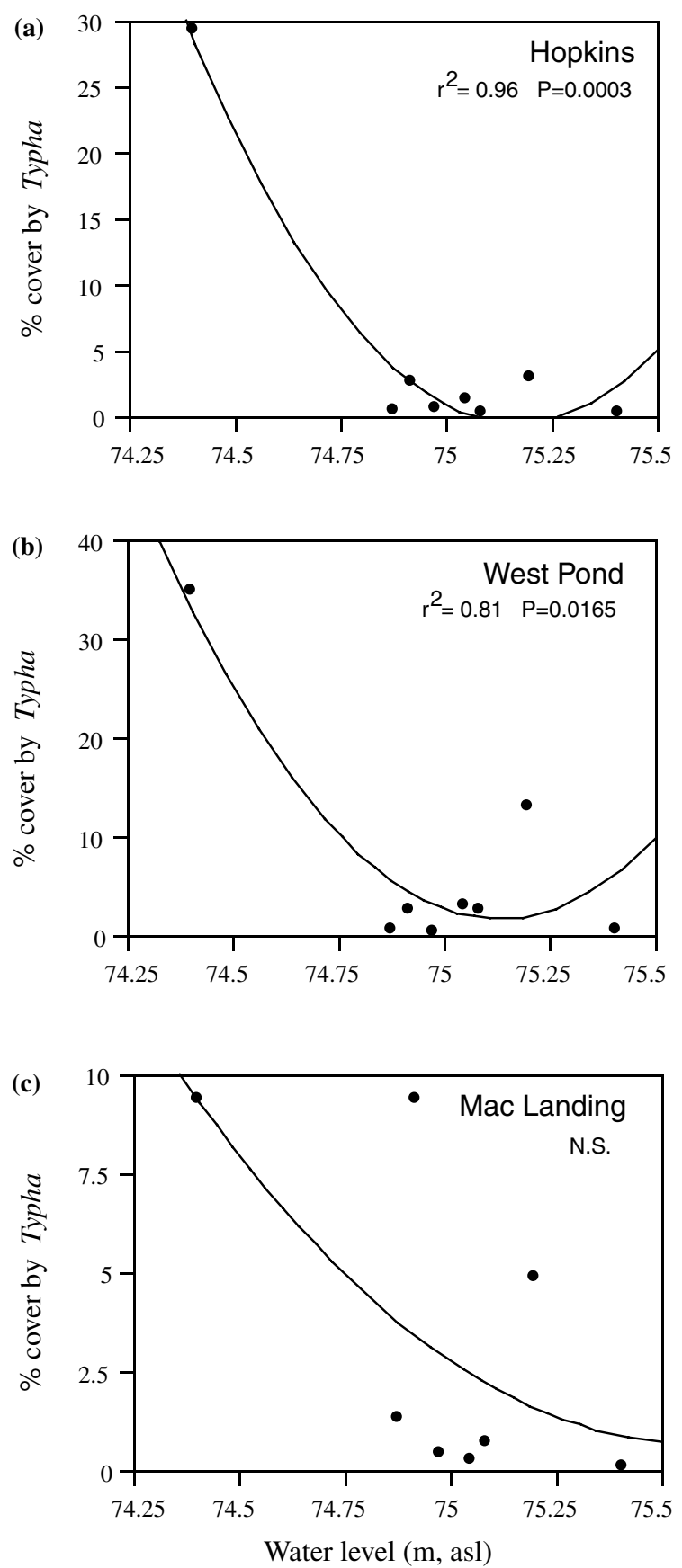

Figure 3. Regression of percentage cover of Typha latifolia with increasing water level in Cootes Paradise Marsh for (a) Hopkins Bay, (b) West Pond and (c) Mac Landing. Only data from 1946 to 1979 are included. 
Table 1. Comparison of mean physical and chemical variables before (B: 1993-1996 inclusive) and after (A: 1997-2001 inclusive) carp exclusion in Cootes Paradise Marsh. Numbers in bracket are SE

\begin{tabular}{|c|c|c|c|c|c|c|c|c|c|}
\hline \multirow[t]{2}{*}{ Parameter } & \multicolumn{3}{|c|}{ LT1 Open-water } & \multicolumn{3}{|c|}{ LT5 West Pond } & \multicolumn{3}{|c|}{ LT8 Mac Landing } \\
\hline & B & A & $p$ & B & A & $p$ & $\mathrm{~B}$ & A & $p$ \\
\hline \multirow[t]{3}{*}{ Wind speed $(\mathrm{m} / \mathrm{s})$} & 2.42 & 2.80 & NS & 2.49 & 1.80 & NS & 1.48 & 0.46 & 0.01 \\
\hline & $(0.38)$ & $(0.30)$ & & $(0.47)$ & $(0.34)$ & & $(0.21)$ & $(0.37)$ & \\
\hline & 28 & 29 & & 26 & 26 & & 25 & 15 & \\
\hline \multirow[t]{3}{*}{ Depth $(\mathrm{cm})$} & 117.6 & 105.0 & NS & 64.0 & 50.8 & 0.04 & 52.2 & 35.6 & $<0.01$ \\
\hline & $(6.48)$ & $(4.29)$ & & $(5.55)$ & $(3.20)$ & & $(5.89)$ & $(2.67)$ & \\
\hline & 29 & 38 & & 27 & 32 & & 25 & 26 & \\
\hline \multirow[t]{3}{*}{ COND $(\mu \mathrm{S} / \mathrm{cm})$} & 655 & 690 & 0.033 & 888 & 894 & NS & 711 & 698 & NS \\
\hline & $(10.7)$ & $(12.1)$ & & $(17.9)$ & $(36.1)$ & & (22.9) & $(30.5)$ & \\
\hline & 37 & 36 & & 36 & 25 & & 23 & 11 & \\
\hline \multirow[t]{3}{*}{ TEMP $\left({ }^{\circ} \mathrm{C}\right)$} & 19.7 & 21.8 & NS & 20.3 & 22.2 & NS & 21.1 & 21.2 & NS \\
\hline & $(0.85)$ & $(0.73)$ & & $(0.98)$ & $(0.92)$ & & $(1.12)$ & $(0.88)$ & \\
\hline & 29 & 36 & & 27 & 26 & & 24 & 23 & \\
\hline \multirow[t]{3}{*}{ EXTINCTION } & 7.24 & 4.82 & 0.008 & 10.05 & 6.33 & 0.009 & 8.16 & 5.34 & NS \\
\hline & $(0.67)$ & $(0.51)$ & & $(1.17)$ & $(0.64)$ & & $(1.33)$ & $(0.87)$ & \\
\hline & 18 & 17 & & 16 & 16 & & 7 & 9 & \\
\hline \multirow[t]{3}{*}{ SECCHI (cm) } & 20.54 & 31.51 & 0.017 & 18.9 & 29.7 & 0.002 & 25.62 & 30.21 & NS \\
\hline & $(2.19)$ & $(3.53)$ & & $(2.75)$ & (1.98) & & $(3.26)$ & $(2.56)$ & \\
\hline & 29 & 38 & & 27 & 32 & & 21 & 21 & \\
\hline \multirow[t]{3}{*}{ TURB (NTU) } & 72.2 & 43.6 & 0.003 & 73.3 & 40.1 & $<0.001$ & 43.1 & 14.2 & $<0.001$ \\
\hline & $(8.76)$ & (4.39) & & $(6.36)$ & $(5.83)$ & & $(4.88)$ & (1.99) & \\
\hline & 29 & 38 & & 27 & 33 & & 25 & 26 & \\
\hline \multirow[t]{3}{*}{ TSS (mg/l) } & 59.0 & 49.4 & NS & 116.2 & 63.3 & 0.02 & 70.1 & 28.5 & $<0.001$ \\
\hline & $(5.21)$ & (5.59) & & (19.8) & $(8.78)$ & & $(9.11)$ & $(3.80)$ & \\
\hline & 38 & 37 & & 37 & 34 & & 23 & 28 & \\
\hline \multirow[t]{3}{*}{ TISS (mg/l) } & 44.1 & 30.0 & 0.03 & 85.1 & 38.7 & 0.01 & 51.9 & 14.6 & $<0.001$ \\
\hline & $(4.58)$ & $(4.52)$ & & (16.4) & (7.03) & & (8.29) & $(2.86)$ & \\
\hline & 38 & 37 & & 37 & 34 & & 23 & 28 & \\
\hline \multirow[t]{3}{*}{$\mathrm{TP}(\mu \mathrm{g} / \mathrm{l})$} & 158 & 157 & NS & 359 & 294 & NS & 208 & 222 & NS \\
\hline & (14.9) & (15.5) & & $(32.6)$ & $(24.8)$ & & $(15.0)$ & (18.9) & \\
\hline & 38 & 37 & & 37 & 33 & & 25 & 27 & \\
\hline
\end{tabular}

$p$ refers to the probability that means are significantly different at $\alpha=0.05$. NS, not significant. Numbers in italics are the sample sizes.

manipulated to simulate both pre- and postexclusion conditions. The mean TSS concentration in carp-free enclosures was $60 \mathrm{mg} / 1$ compared with $80-90 \mathrm{mg} / 1$ in enclosures where the number and size of carp had been manipulated to approximate spawning conditions in the marsh during a 1994 survey. Based on their results, they predicted that water clarity in Cootes Paradise Marsh should improve by $25-33 \%$ following carp exclusion. However, since TSS concentrations decrease significantly with water level (Chow-Fraser et al., 1999a), the effect of carp exclusion on water clarity should not be evaluated without accounting for inter-annual differences in water depth.

To correct for the effect of water level, I plotted post-exclusion data as a function of water level and compared these with similar pre-exclusion data. To control for site-to-site variation, I used only data from Site 1 since it was the only station deep enough to be monitored throughout the summer in all years. TSS concentrations corresponding to the pre-exclusion period (1986-1996) were plotted against mean summer water level (May-September inclusive) and this resulted in a 
significant negative relationship (closed symbols in Fig. $\left.4 ; r^{2}=0.688 ; p=0.003\right)$. When I superimposed post-exclusion data (open symbol in Fig. 4) on the same graph, all data except that for 1997 fell within the $95 \%$ confidence limit of the best-fit line. Measured post-exclusion concentrations were $10-44 \%$ lower than that expected based on water levels alone, with an average of $22 \%$ for the 4 years. These results are therefore remarkably consistent with predictions of Lougheed et al. (1998) that carp exclusion would reduce TSS concentrations by about 25-33\%.

\section{Submergent vegetation}

I evaluated the response of the SAV to changes in water level by determining the change in total stem density in Cootes Paradise Marsh before and after the biomanipulation. Since the response of the SAV community was most pronounced in the embayments, I restricted my analysis to the marsh transects taken in embayments located at the west end (see Fig. 1). Data from Lougheed et al. (2004) showed that Potamogeton pectinatus, which was the only species reported in the embayment prior to biomanipulation (Chow-Fraser et al., 1998; Lundholm \& Simser, 1999), remained the

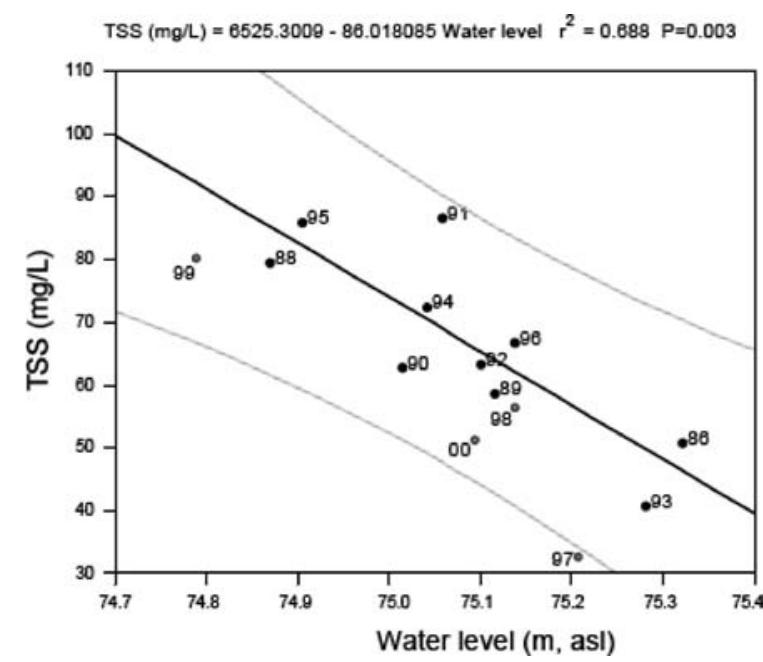

Figure 4. Mean summer TSS concentration $(\mathrm{mg} / \mathrm{l})$ for each year regressed as a function of mean summer water level (m, asl). Biweekly TSS data collected from May-September have been included. Open circles (corresponding to post-exclusion years) were not included in the regression of the best-fit line. Lines indicating the $95 \%$ confidence intervals for the regression line are also plotted. dominant species after biomanipulation from 1997 to 2000 (Fig. 5). In 1997, average stem densities in the marsh were less than 5000; however, 1 year following carp exclusion, stem densities exceeded 30,000 , and growth was profuse, especially in the marsh transects (in the vicinity of Hopkin's Landing and Mac Landing). During that year, other submersed species reached relatively high numbers including Elodea canadensis, Potamogeton crispus, P. foliosus, Ceratophyllum demersum and Myriophyllum spicatum; by comparison, Zannichellia palustris and Vallisneria americana were present but not very abundant.

There was a mean difference in water levels between 1998 and 1999 of greater than $35 \mathrm{~cm}$ (see Fig. 5b). This difference may have been inconsequential in the deep, open-water areas of Cootes Paradise, but in the shallow embayments (e.g. Mac Landing), where the seasonal mean depth can be as low as $23 \mathrm{~cm}$, and frequently less than $40 \mathrm{~cm}$, a difference of $35 \mathrm{~cm}$ between years can be substantial. This drop in water level coincided with a sharp decrease of more than half the stem density in 1999 (Fig. 5a). Despite an increase in water level in 2000 , the SAV community continued to decline, and dropped to levels reminiscent of the pre-exclusion period (i.e. 1996). One reason for the lower stem count in 1999 may have been because light levels had been inadequate to support the germination and growth of SAV, since lower water levels tend to be associated with higher TSS concentrations (Fig. 5).

I decided to test this hypothesis using $Z_{\max }$, a parameter commonly used by limnologists to estimate the maximum depth at which SAV colonize lakes and rivers (e.g. Chambers \& Kalff, 1985). Although $Z_{\max }$ can be estimated from Secchi depth transparencies (Chambers \& Kalff, 1985; Duarte et al., 1986) and from light extinction coefficients (Hudon et al., 2000) (Fig. 6a and b, respectively), the HHRAP favoured the use of SECCHI in their analysis of Cootes Paradise Marsh (e.g. Painter et al., 1989) and therefore, I decided to examine SECCHI depth relationships first. Both of the relationships derived from lake data (i.e. Chambers \& Kalff, 1985; Duarte \& Kalff, 1986) yielded very similar $Z_{\max }$ values. The relationship derived from riverine wetland (Hudon et al., 2000), however, yielded $Z_{\max }$ values that were very different at high SECCHI depth readings (Fig. 6a). All three relationships converged at 

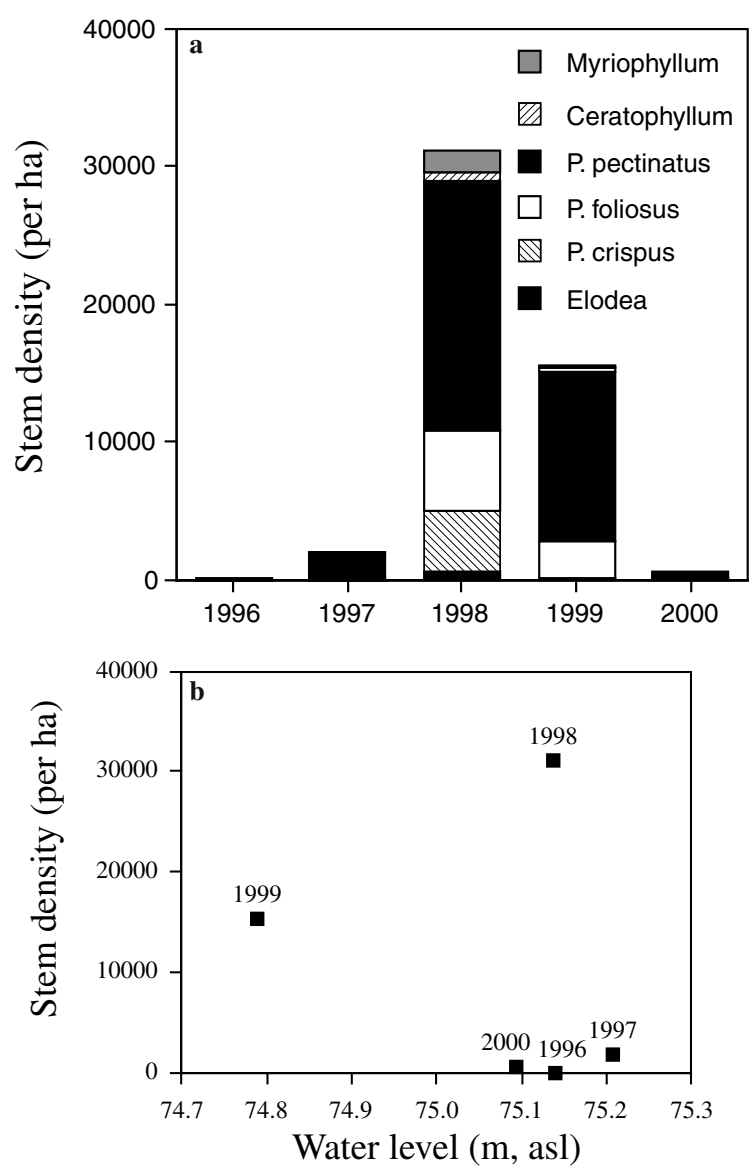

Figure 5. (a) Changes in mean stem density of submersed macrophytes in Cootes Paradise from 1996 to 2000 for Elodea canadensis, Potamogeton crispus, P. foliosus, P. pectinatus, Ceratophyllum demersum, and Myriophyllum spicatum. Data were obtained from Lougheed et al. (2004). (b) Plot of mean stem density of submersed macrophytes in Cootes Paradise from 1996 to 2000 versus mean seasonal water level (calculated for May-September inclusive).

about $1.5 \mathrm{~m}$, but diverged again at low SECCHI readings. Since the relevant range for the present study included values less than $1.0 \mathrm{~m}$, and there was no basis for choosing one over the other two relationships, I decided not to indiscriminantly apply any of the equations, and instead used Hudon et al.'s (2000) equation which related $Z_{\max }$ to EXTINCTION data.

Prior to biomanipulation (1994 and 1996), the predicted $Z_{\max }$ values were generally shallower than the mean depth of the open-water station (open square) and the sewage lagoon (open circle; Fig. 6b). This suggests that light levels near the
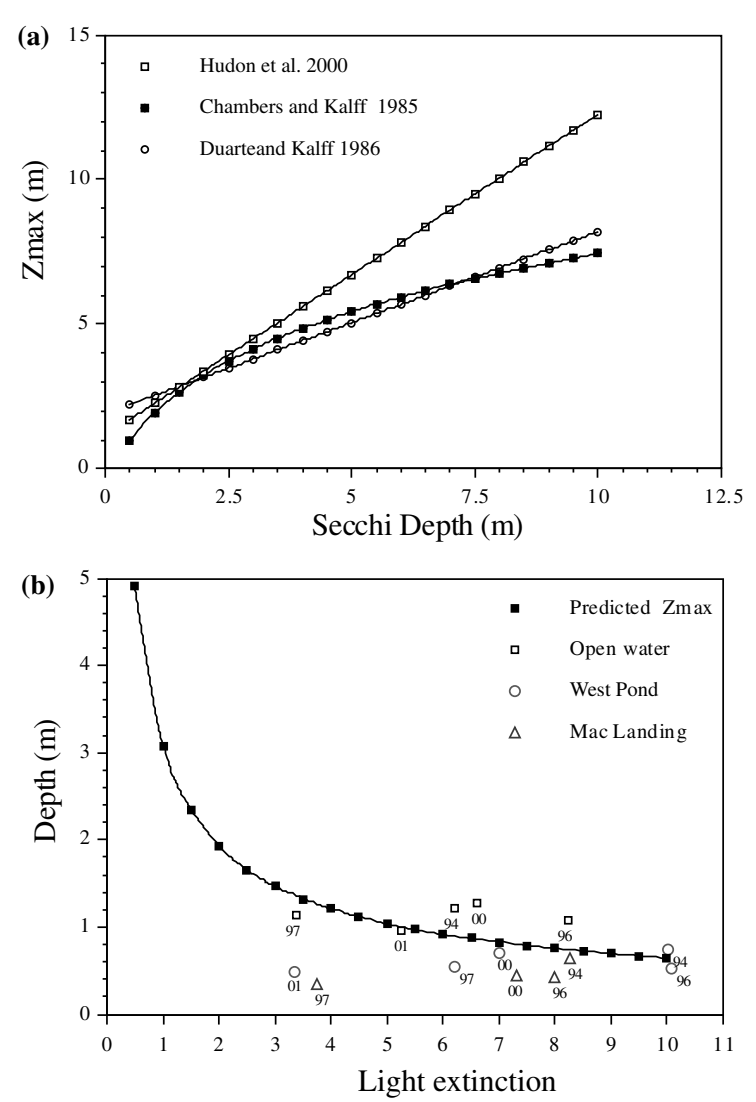

Figure 6. (a) Relationship between $Z_{\max }(\mathrm{m})$ and Secchi depth (m) according to Hudon et al. (2000; $Z_{\max }=1.11 *$ SECCHI $\left.+1.16 ; r^{2}=0.81\right)$, Chambers \& Kalff $\left(1985 ; Z_{\max }{ }^{0.5}=\right.$ $\log _{10}$ SECCHI $\left.* 1.33+1.40 ; r^{2}=0.58\right)$ and Duarte \& Kalff $\left(1986 ; Z_{\max }=0.63^{*}\right.$ SECCHI $\left.+1.90 ; r^{2}=0.76\right)$. (b) Relationship between $Z_{\max }(\mathrm{m})$ and Extinction coefficient according to Hudon et al. (2000; $Z_{\max }=3.08$. EXTINCTION ${ }^{-0.675}$; $\left.r^{2}=0.82\right)$. Mean depth $(\mathrm{m})$ at the three sampling stations in 1994, 1996, 1997 and 2000 are also plotted.

sediment may not have been sufficient to support the germination and growth of SAV at these deeper stations prior to carp exclusion. By comparison, $Z_{\max }$ values were always deeper than the mean depth at Mac Landing, suggesting that light was probably not a limiting factor in such shallow embayments. This interpretation is consistent with observations that $P$. pectinatus, $P$. foliosus and Elodea canadensis were able to grow in field enclosures near Mac Landing during pre-manipulation years (Chow-Fraser, 1999b). Therefore, except for the very deep, open-water site (mean depth $>1.0 \mathrm{~m}$ ), light levels at the sediment surface in the embayments were probably sufficient to 
support growth of turbidity-tolerant SAV even prior to the marsh-wide removal of carp. On the other hand, $Z_{\max }$ tended to be shallower than the average depth of the water column at Site 1 and this suggests that light conditions may have been limiting SAV growth in the eastern portion of the marsh, even after carp exclusion (i.e. in 1994, 1996 and 2000).

In many coastal marshes such as Cootes Paradise, water levels are generally too low by midsummer to collect light measurements for EXTINCTION calculations when water levels are low. For this reason, and because EXTINCTION data can be very tedious to collect, I have used TSS and TURB (both considerably easier to collect) to predict extinction coefficient (Fig. 7a and $\mathrm{b}$, respectively). The graphs show clearly that the relationship can be applied equally to pre-and
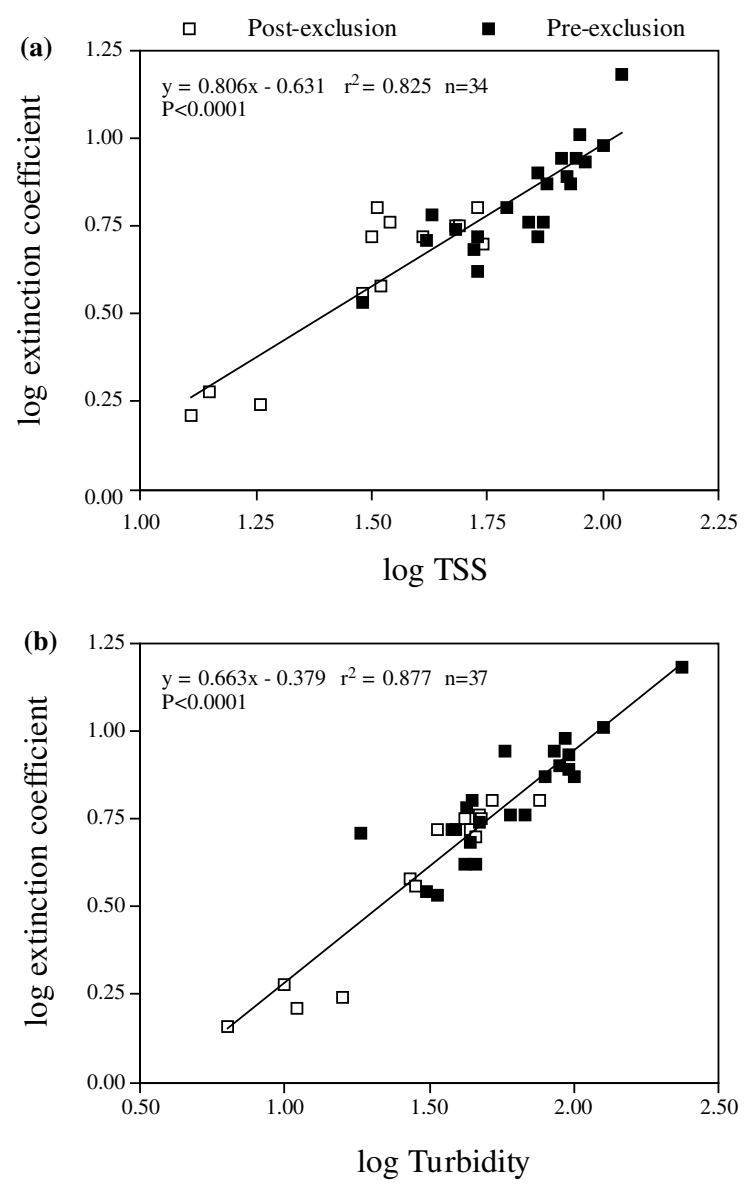

Figure 7. $\log _{10}$ extinction coefficient as a function of (a) $\log _{10}$ TSS (mg/L) and (b) $\log _{10}$ TURB (NTU) for pre-exclusion (closed squares) and post-exclusion (open squares) data. post-biomanipulation periods, and should be generally applicable for future monitoring programs.

\section{Discussion}

Water depth and nutrient status are two key determinants of the type and quantity of emergent vegetation in many types of wetland ecosystems (Grace \& Wetzel, 1981; Day et al., 1988; Hudon, 1997). Studies on coastal Great Lakes wetlands have tended to focus on water depth and investigators have generally ascribed the loss of emergent wetland cover to increased water depth alone, although increased fertility through anthropogenic inputs have also been implicated in more recent studies (Lyon \& Drobney, 1986; Williams, 1995; Chow-Fraser et al., 1998; Gottgens et al., 1998; Wilcox et al., 2003). Over the past half century, mean annual water levels in Lake Ontario have tended to be above the long-term mean (Fig. 8a), and Quinn (2002) has concluded that the regulation of the water level after 1958 has resulted in a seasonal range that is $10 \mathrm{~cm}$ higher than that prior to regulation. In addition, there has been a more robust seasonal cycle, with higher summer maxima and lower fall minima, occurring about a month earlier in the decades following regulation (Fig. 8b). These conditions, along with the unusually low water levels during the 1930s which coincided with the initial marsh survey, meant that Cootes Paradise Marsh has experienced sustained high water depths over the past century, to the detriment of the emergent plant community.

The non-linear relationship between percent cover and water level for Cootes Paradise Marsh (Fig. 2b) described more of the residual variation than did the linear regression (Fig. 2a). This suggests there is a threshold water level (depth) for emergent vegetation, above which the percentage cover will be kept low. Below the threshold value, however, there appears to be a disproportionate effect of drawdown, and this may be reflective of the specific contours of the marsh that corresponds to a greater rate of mudflat being exposed below $74.4 \mathrm{~m}$ asl (Fig. 2b). There has also been an increase in urbanization in the watershed over the six decades that may have contributed to the damage of aquatic vegetation in the marsh, and 

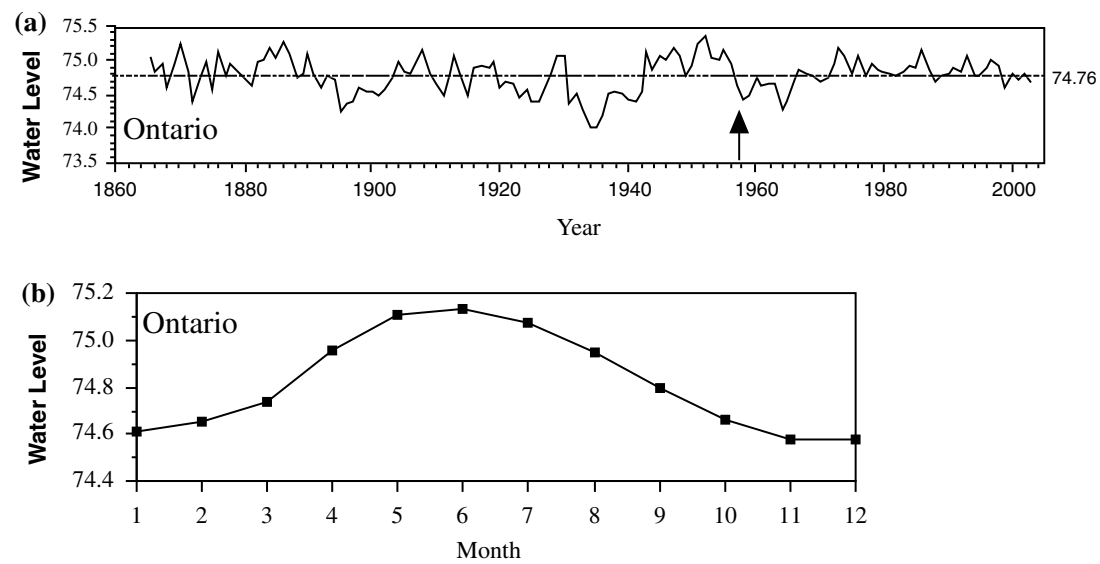

Figure 8. (a) Mean annual water level data for Lake Ontario (for gauge at Oswego, NY, USA.) from National Oceanic and Atmospheric Administration (NOAA) covering the period from January 1865 to July 2003. Complete description of the dataset have been published by Lenters (2001) and Quinn (2002). (b) Mean monthly water level data (as above) for Lake Ontario calculated for the period from 1950 to 2003 inclusive.

this possibility is being investigated in a separate paper (Wei \& Chow-Fraser, 2005).

According to Lee et al. (2004), Zizania aquatica (wild rice) was one of the dominant wetland grasses present in Cootes Paradise Marsh (Dundas Marsh in their study) 1000 years ago, when the marsh was presumably deeper, because wild rice is an annual that grows in relatively deep water, where the submersed juvenile stage requires good light penetration (Crowder \& Bristow, 1988; Newman et al., 1996; Doyle, 2001). The presence of pollen from Nuphar and Nymphaea also provides supporting evidence that the marsh had been deeper at that time. Wild rice was replaced by Typha latifolia, Sparganium sp., and Thelypteris sp. at roughly the time of European settlement, when deforestation in the watershed probably accelerated sediment accretion and nutrient enrichment. This proposed succession is consistent with observations that cattail and burreed require shallower water, with greater organic content (Grace \& Wetzel, 1981; Day et al., 1988; Wisheu et al., 1990). In particular, the dominance of Typha latifolia is predictable because of its competitive superiority in shallow water and relatively fertile soils (Grace, 1987; Stewart et al., 1997). It is important to note, however, that even by the late 18th century, wild rice had still been part of the pollen record (Lee et al., 2004), and according to accepted folk lore, aquatic plants, including wild rice, used to line the main channel in the marsh during the 1800 s and prevented boat access to the growing town of Dundas. Therefore, loss of plant diversity in the marsh accelerated in the 19th century, but was not severe until almost the 20th century.

Chow-Fraser (1998) has already documented reasons for evolution of the shallow, cattail marsh in the early part of the 20th century to the deep, open-water, turbid system that we see today. Although development of the town of Dundas initially led to marsh infilling, continued urbanization resulted in a net loss of sediment to Cootes Paradise Marsh due to alteration of marsh hydrology (dredging and channelization), and retention of sediment via construction of two reservoirs on upper Spencer's Creek, the main tributary of Cootes Paradise (Smith, 1995). These events essentially increased water depth in the marsh over the past century, independent of the post-glacial isostatic rebound that is estimated to have contributed an additional $18-30 \mathrm{~cm}$ to water depth over this time (Smith, 1995). Superimposed on these is the increased elevation of Lake Ontario over the past half century as discussed earlier (Fig. 8a), and it is not difficult to see why the emergent vegetation declined dramatically from 1934 to 1993 (Fig. 2). The return of the emergent vegetation in 1999 when water levels in Lake Ontario dropped to such favourable levels was highly predictable. In Figure $2 \mathrm{a}$ and $\mathrm{b}$, the location of 1999 relative to the line of best fit indicate clearly that the slight 
recovery of emergent vegetation noted by Smith et al. (2001) could have been attributed to lower water levels alone. In the absence of a control, it is difficult to attribute the growth of emergent vegetation to carp exclusion rather than to reduced water depth, especially since species that dominated in 1999 tended to be those perennials (e.g. Typha sp. and Lythrum salicaria) and annuals (Leersia oryzoides) that germinate only on newly exposed mudflats.

The revitalization of species diversity, comparable to levels observed prior to the 1970s (ChowFraser et al., 1998) may be partially attributed to reduced water turbidity in 1997 following carp exclusion (Table 1 and Fig. 4). However, Lougheed et al. (2004) has shown that the delayed migration of planktivores into the marsh due to an exceptionally cool spring induced a trophic cascade that led to a clear-water phase. Large Daphnia, which had been released from predation in early summer, reached unprecedented numbers in the open-water areas, and grazed down the algal community to the point that $Z_{\max }$ uncharacteristically exceeded seasonal mean depth at Site 1 in 1997 (Fig. 5b). Samples of Daphnia have been examined to verify that the gut contents during this episode contained large quantities of both algae and sediment.

The main reason that I attribute very little of the reduction in turbidity to carp exclusion is because large Daphnia had also been found in unusually high numbers in spring of 1997 at Station 258 in Hamilton Harbour, where carp had not been excluded (Chow-Fraser, unpublished data). A biweekly sampling program conducted in the harbour from 1995 to 1997 showed clearly that the abundant Daphnia throughout the water column in May 1997 was inconsistent with May distributions sampled in 1995 and 1996. The prominence of Daphnia in the water coincided with significant increases in Secchi depth that returned to low values when the alewife arrived in early June. This was followed by an eventual resurgence of algal biomass in both Cootes Paradise and Hamilton Harbour that were similar in magnitude to levels observed during pre-biomanipulation years (Lougheed et al., 2004; Chow-Fraser, unpublished data).

I speculate that the greatly increased water transparency in 1997 stimulated the growth of Potamogeton pectinatus, and at least some of the other species (P. foliosus, $P$. crispus, Elodea canadensis, Ceratophyllum demersum and Myriophyllum spicatum), which was the reason for their abundance in the 1998 survey (Fig. 4a). These species are indicative of eutrophic waters, and are very tolerant of high water turbidity (Lougheed et al., 1998; Lougheed et al., 2001). Rather than germinating from seeds, these submergent species reproduce asexually from tubers and turions that can remain viable in the sediment for many years (Lundholm \& Simser, 1999), and this is consistent with the observation that only a few viable seeds were found in a 1991 seed survey of Cootes Paradise (Westcott et al., 1997). Mac Landing appeared to have been less wind-disturbed in the years following carp exclusion (Table 1), and this may also have helped in the fast recovery of SAV during 1997 and 1998.

For degraded marshes such as Cootes Paradise Marsh, there appears to be two threshold water levels for the SAV community. First, there is a maximum threshold, above which light availability becomes limiting (i.e. open water site in 1994 and 1996 Fig. 6b), and it may be simple to establish this threshold by measuring ambient light levels. Harwell and Havens (2003) also reported this type of light limitation on the growth of submersed macrophytes during years of above-average water levels in Lake Okeechobee. Secondly, there is a minimum threshold, below which conditions are too dry to support SAV, and this threshold level may be very difficult to ascertain in the field, and may ultimately depend on the species composition of the community. Since the maximum percentage germination in dry sediment is significantly lower than that in wet sediment (Harwell \& Havens, 2003), I speculate that the disappearance of the submergent taxa in Cootes Paradise in 1999 is due primarily to the combined effects of desiccation, and the constant re-burial of propagules due to wind resuspension when the water is shallow. Even in the absence of common carp, the high wave energy in the open-water areas of Cootes Paradise can disturb the sediment and erode the propagule bank (Sager et al., 1998).

Long-term water-level fluctuations in Lake Ontario are primarily driven by cyclical variations in basin supply, which have resulted in low levels roughly every 30 years (mid 1890s, 1930s, 1960s, and more recently in the late 1990s (Fig. 8). 
Regional factors such as isostatic crustal rebound and water level regulation for navigation have led to an overall increase in water level over the past century. Site-specific factors, such as the creation of two reservoirs on Spencer's Creek, and hydrologic alterations within the marsh (dredging and channelization) have caused a net loss of sediment that has further contributed to high water depths. It is likely that prior to European settlement, the marsh supported a fairly stable deep-water community dominated by wild rice and other grains, and that these may have co-existed with a diverse community of submergent and floating vegetation, similar to the deep, clear-water marshes that currently exist in less disturbed areas of Lake Ontario (e.g. Presqu'ile, Bay of Quinte marshes; Lougheed et al., 2001; McNair \& Chow-Fraser, 2003; Lee et al., 2004). Ironically, we are now entering another period of low water levels that not only reflects natural variation in weather patterns, but also the effects of global climate change (Mortsch, 1998). Given the strong response of the emergent community to water-level reductions, and predictions of continued low water levels in the Great Lakes due to global climate change, it is very likely that the emergent marsh will continue to rebound even in the absence of a carp-exclusion program.

Removal of most of the common-carp population from Cootes Paradise resulted in a predictable decrease in TSS of about $25 \%$, after the effects of inter-annual differences in water level was taken into account (Fig. 4). This level of reduction will not likely benefit the SAV community since light is probably not limiting in the shallow areas where the plant communities have the best chance of regenerating, owing to better protection from wind and wave disturbance. In the deep, open-water sites, however, the light environment near the sediment surface did not appear to be sufficient to support growth of SAV prior to carp exclusion, but, unfortunately, even after the biomanipulation, $Z_{\max }$ was still considerably shallower than the mean depth at these sites. The type of ecosystem-level sampling included in this study (i.e. water-quality parameters, plant surveys as well as information on the plankton and planktivore community) must be carried out as part of any effectiveness-monitoring program if we are to fully understand the impacts of carp exclu- sion and fluctuating water levels on the recovery of degraded marshes of the Great Lakes.

\section{Acknowledgements}

Over the years, many people, especially V. Lougheed, A. Wei, J. Lundholm and S. McNair have contributed ideas that shaped my thinking of Cootes Paradise Marsh. I want to thank A. Wei for his assistance with map-making, and for comments on an earlier draft. The review of two anonymous reviewers greatly improved the final manuscript. I also want to thank K. Havens and H. Coops for suggesting this topic.

\section{References}

Angeler, D. G., P. Chow-Fraser, M. A. Hanson \& S. SanchezCarrillo, 2003. Biomanipulation: a useful tool for freshwater wetland mitigation? Freshwater Biology 48: 2203-2213.

Argyilan, E. P. \& S. L. Forman, 2003. Lake level response to seasonal climatic variability in the Lake Michigan-Huron system from 1920 to 1995. Journal of Great Lakes Research 29: 488-500.

Chambers, P. A. \& J. Kalff, 1985. Depth distribution and biomass of submersed aquatic macrophyte communities in relation to secchi depth. Canadian Journal of Fisheries and Aquatic Sciences 42: 701-709.

Chow-Fraser, P., 1998. A conceptual ecological model to aid restoration of Cootes Paradise Marsh, a degraded coastal wetland of Lake Ontario, Canada. Wetland Ecology and Management 6: 43-57.

Chow-Fraser, P., 1999a. Seasonal, interannual, and spatial variability in the concentrations of total suspended solids in a degraded coastal wetland of Lake Ontario. Journal of Great Lakes Research 25: 799-813.

Chow-Fraser, P., 1999b. Volunteer-based experimental planting program to restore Cootes Paradise Marsh, an urban coastal wetland of L. Ontario. Lakeline 19(1).

Chow-Fraser, P. \& D. Albert, 1999. Coastal wetland ecosystems: biodiversity investment areas. In: State of the Lakes Ecosystem Conference 1998.

Chow-Fraser, P., V. L. Lougheed, V. Le Thiec, B. Crosbie, L. Simser, \& J. Lord, 1998. Long-term response of the biotic community to fluctuating water levels and changes in water quality in Cootes Paradise Marsh, a degraded coastal wetland of Lake Ontario. Wetlands Ecology and Management 6: 19-42.

Crowder, A. \& J. M. Bristow, 1988. The future of waterfowl habitats in the Canadian lower Great Lakes wetlands. Journal of Great Lakes Research 14: 115-127.

Day, R. T., P. A. Keddy, J. McNeill \& T. Carleton, 1988. Fertility and disturbance gradients: a summary model for riverine marsh vegetation. Ecology 69: 1044-1054.

Doyle, R. D., 2001. Effects of waves on the early growth of Vallisneria americana. Freshwater Biology 46: 389-397. 
Duarte, C. M., J. Kalff \& R. H. Peters, 1986. Patterns in biomass and cover of aquatic macrophytes in lakes. Canadian Journal of Fisheries and Aquatic Sciences 43: 1900-1908.

Environment Canada \& U.S. Environmental Protection Agency, 1995. The Great Lakes: Environmental Atlas and Resource Book. 3rd edn. 46 pp.

Gottgens, J. G., B. P. Swartz, R. W. Kroll \& M. Eboch, 1998. Long-term GIS-based records of habitat changes in a Lake Erie coastal marsh. Wetlands Ecology and Management 6: 5-17.

Grace, J. B., 1987. The impact of pre-emption on the zonation of two Typha species along lakeshores. Ecological Monographs 57: 283-303.

Grace, J. B. \& R. G. Wetzel, 1981. Phenotypic and genotypic components of growth and reproduction in Typha latifolia: experimental studies in marshes of differing successional maturity. Ecology 52: 789-801.

Harwell, M. C. \& K. E. Havens, 2003. Experimental studies on the recovery potential of submerged aquatic vegetation after flooding and dessication in a large subtropical lake. Aquatic Botany 77: 135-151.

Herdendorf, C. E., 1992. Lake Erie coastal wetlands: an overview. Journal of Great Lakes Research 18: 533-551.

Hudon, C., 1997. Impact of water level fluctuations on St. Lawrence River aquatic vegetation. Canadian Journal of Fisheries and Aquatic Sciences 54: 2853-2865.

Hudon, C., S. Lalonde \& P. Gagnon, 2000. Ranking the effects of site exposure, plant growth form, water depth, and transparency on aquatic plant biomass. Canadian Journal of Fisheries and Aquatic Sciences 57 (Suppl. 1): 31-42.

Keddy, P. A. \& A. A. Rezniceck, 1986. Great Lakes vegetation dynamics: the role of water levels and buried seeds. Journal of Great Lakes Research 12: 25-36.

Lee, G. A., A. M. Davis, D. G. Smith \& J. H. McAndrews, 2004. Identifying fossil wild rice (Zizania) pollen from Cootes Paradise, Ontario: a new approach using scanning electron microscopy. Journal of Archeaological Sciences 31: 411-421.

Lenters, J. D., 2001. Long-term trends in the seasonal cycle of Great Lakes water levels. Journal of Great Lakes Research 27: 342-353.

Lougheed, V. L. \& P. Chow-Fraser, 1998. Factors that regulate the community structure of a turbid, hypereutrophic Great Lakes wetland. Canadian Journal of Fisheries and Aquatic Sciences 55: 150-161.

Lougheed, V. L. \& P. Chow-Fraser, 2001. Spatial variability in the response of lower trophic levels after carp exclusion from a freshwater marsh. Journal of Aquatic Ecosystem Stress and Recovery 9: 21-34.

Lougheed, V. L. \& P. Chow-Fraser, 2002. Development and use of a zooplankton index to monitor wetland quality in the Laurentian Great Lakes basin. Ecological Applications 12: 474-486.

Lougheed, V. L., B. Crosbie \& P. Chow-Fraser, 1998. Predictions on the effect of carp exclusion on water quality, zooplankton \& submergent macropytes in a Great Lakes wetland. Canadian Journal of Fisheries and Aquatic Sciences 55: 1189-1197.
Lougheed, V. L., B. Crosbie \& P. Chow-Fraser, 2001. Primary determinants of macrophyte community structure in 62 marshes across the Great Lakes basin. Canadian Journal of Fisheries and Aquatic Sciences 58: 1603-1612.

Lougheed, V. L., T. Theÿsmeÿer, T. Smith \& P. Chow-Fraser, 2004. Carp exclusion, food-web interactions, and the restoration of Cootes Paradise Marsh. Journal of Great Lakes Research 30: 44-57.

Lundholm, J. T. \& W. L. Simser, 1999. Regeneration of submerged macrophyte populations in a disturbed Lake Ontario coastal marsh. Journal of Great Lakes Research 25: 395400.

Lyon, J. G. \& R. D. Drobney, 1986. Lake level effects as measured from aerial photos. Journal of Surveying Engineering 110: 103-111.

McNair, S. A. \& P. Chow-Fraser, 2003. Change in biomass of benthic and planktonic algae along a disturbance gradient for 24 Great Lakes coastal wetlands. Canadian Journal of Fisheries and Aquatic Sciences 60: 676-689.

Mortsch, L. D., 1998. Assessing the impact of climate change on the Great Lakes shoreline wetlands. Climatic Change 40: 391-416.

Newman, S., J. B. Grace \& J. W. Koebel., 1996. Effects of nutrients and hydroperiod on Typha, Cladium, and Eleocharis: implications for Everglades restoration. Ecological Applications 6: 774-783.

Painter, D. S., K. J. McCabe \&.L. Simser, 1989. Past and present limnological conditions in Cootes Paradise affecting aquatic vegetation. National Water Research Institute (NWRI) Contribution No. 88-47.

Quinn, F. H., 2002. Secular changes in Great Lakes water level seasonal cycles. Journal of Great Lakes Research 28: 451-465.

Sager, E. P. S., 1996. Factors influencing the light environment in Cootes Paradise, Hamilton Harbour, and other coastal marshes of Lake Ontario. Water Quality Research Journal of Canada 31: 553-575.

Sager, E. P. S., T. H. Whillans \& M. G. Fox, 1998. Factors influencing the recovery of submersed macrophytes in four coastal marshes of Lake Ontario. Wetlands 18: 256-265.

Smith, D. G., 1995. Cootes Paradise Marsh and stream restoration: a geomorphologic perspective. Report to the Hamilton Harbour Remedial Action Plan. 23 pp.

Smith, T., J. Lundholm \& L. Simser, 2001. Wetland vegetation monitoring in Cootes Paradise: measuring the response to a fishway/carp barrier. Ecological Restoration 19: 145-154.

Stewart, H., S. L. Miao, M. Colbert \& C. E. Carraher, Jr., 1997. Seed germination of two cattail (Typha) species as a function of Everglades nutrient levels. Wetlands 17: 116-122.

Wei, A. \& P. Chow-Fraser 2005, Untangling the confounding effects of urbanization and high water level on the cover of emergent vegetation in Cootes Paradise marsh, a degraded coastal wetland of Lake Ontario. Hydrobiologia (in press).

Wei, A., P. Chow-Fraser \& D. Albert, 2004. Influence of shoreline features on fish distribution in the Laurentian Great Lakes. Canadian Journal of Fisheries and Aquatic Sciences 61: 1113-1123.

Westcott, K., T. H. Whillans \& M. G. Fox, 1997. Viability and abundance of seeds of submerged macrophytes in the sediment of disturbed and reference shoreline marshes 
in Lake Ontario. Canadian Journal of Botany 75: 451-456.

Wetzel, R. G., 1992. Wetlands as metabolic gates. Journal of Great Lakes Research 18: 529-532.

Wilcox, D. A. \& T. H. Whillans, 1999. Techniques for restoration of disturbed coastal wetlands of the Great Laakes. Wetlands 19: 835-857.

Wilcox, K. L., S. A. Petrie, L. A. Maynard \& S. W. Meyer, 2003. Historical distribution and abundance of Phragmites australis at Long Point, Lake Erie, Ontario. Journal of Great Lakes Research 29: 664-680.

Williams, D. C. 1995. Dynamics of area changes in Great Lakes coastal wetlands influenced by long-term fluctuations in water levels. Ph.D thesis, University of Michigan, $182 \mathrm{pp}$.

Wisheu, I. C., P. A. Keddy, D. R. J. Moore, S. J. McCanny \& C. L. Gaudet, 1990. Effects of eutrophication on wetland vegetation. Proceedings of an International Symposium Wetlands of the Great Lakes. Niagara Falls, NY, May 16-18. 